\title{
Analisis Potensi Pajak Parkir Terhadap Pendapatan Asli Daerah (PAD) Di Mall-Mall Kota Pekalongan
}

\author{
Nadyatul Khusna ${ }^{1}$, Hendriyati Haryani ${ }^{2}$, Rizka Mukhlisiah ${ }^{3}$ \\ ${ }^{1}$ Prodi Akuntansi Syariah Institut Agama Islam Negeri Pekalongan, ${ }^{2,3}$ Program Studi Akuntansi \\ Universitas Raharja \\ Email : ${ }^{* 1}$ Nadyagefani@gmail.com, ${ }^{2}$ hendriyati@ raharja.info, ${ }^{3}$ rizka.mukhlisiah@ raharja.info
}

\begin{abstract}
Abstrak
Berbagai macam permasalahan yang timbul dari pajak parkir di Mall-Mall Kota Pekalongan seperti diperlukannya jaminan keamanan dan kenyamanan bagi pengguna jasa parkir, pajak parkir masih bisa memenuhi targetnya dan masih bisa berperan terhadap Pendapatan Asli Daerah di Mall-Mall Kota Pekalongan. Dari latar belakang tersebut penulis kemudian ingin membahasnya dalam Artikel dengan judul "Analisis Potensi Pajak Parkir Terhadap Pendapatan Asli Daerah (Pad) Di Mall-Mall Kota Pekalongan", Apapun fokus masalah dalam penelitian ini adalah bagaimana peran pajak parkir terhadap Pendapatan Asli Daerah di Mall-Mall Kota Pekalongan, bagaimana dukungan pajak parkir dalam mengoptimalkan Pendapatan Asli Daerahnya di Mall-Mall Kota Pekalongan.
\end{abstract}

Kata kunci : Potensi Pajak Parkir, Pendapatan Asli Daerah (PAD) di Mall-Mall Kota Pekalongan.

\begin{abstract}
A wide range of issues arising from tax in the Mall parking lot Pekalongan City Mall as the need for security and comfort of the consumer vehicle, the parking tax could stiil meet its targets and can still contribute to local revenue in Mall - Mall Pekalongan. Departure from that background that $i$ will want to discuss the thesis with the title "ANALISIS POTENTIAL TAX REVENEW TO PARKING AREA (PAD) IN MALL-MALL PEKALONGAN CITY". The focus of the problem in this research is how the role of the parking tax to Revenue in the MallMall Pekalongan, how to optimize your support in the parking tax to Revenue in the Area of Mall-Mall Pekalongan. Researchers do research using a qualittative approach. The autor uses the method of observation, document ation, and interviews. As for the data analysis the author use the analisys and potential tax efficiency to optimize parking. Result can be delivered by the author roles parking tax t........... MNo revenue Mall-Mall Pekalongan can be seen from every Mall that contributed to the original income in Pekalongan, can also indirectly have a positive impact both on the goverment Pekalongan.
\end{abstract}

Keywords: Potential Parking Tax, Revenue (PAD) in the mall-mall Pekalongan.

\section{Pendahuluan}

Berdasarkan UUD 1945 yang menempatkan perpajakan sebagai salah satu perwujudan kenegaraan, ditugaskan bahwa penempatan beban kepada rakyat seperti pajak dan lain-lainnya harus ditetapkan dengan Undang-Undang, demikian pula pendapatan daerah juga harus didasarkan pada Undang-Undang Nomor 28 Tahun 2009. Pajak dibebankan kepada masyarakat oleh pemerintah, hal ini merupakan kebijakan dari pemerintah sehingga perlu dijaga agar kebijakan tersebut dapat memberikan yang adil sejalan dengan sistem perpajakan Indonesia. Pemerintah pusat dalam pemungutan pajak daerah hanya berperan untuk menjaga dan 
mengawasi. Hal ini berdasarkan undang-undang otonomi kodaerah dan pajak daerah yang berasal dari Negara yang berdasarkan undang-undang perimbangan keuangan antara pemerintah pusat dan pemerintah daerah.

Selama ini pemungutan Daerah baik berupa Pajak dan Retribusi diatur dengan UndangUndang Nomor 18 Tahun 1997 mengatur tentang Pajak Daerah dan Retribusi Daerah sebagaimana telah diubah dengan Undang-Undang Nomor 34 Tahun 2000. Kedua UndangUndang Nomor 28 Tahun 2009. Pelaksanaan kewenangan pemerintah daerah sebagaimana ditetapkan dalam Undang-Undang Nomor 32 Tahun 2004 tentang Pemerintahan Daerah yang diikuti dengan Undang-Undang Nomor 33 tahun 2004 tentang perimbangan keuangan antara Pemerintah Pusat dan Pemerintah Daerah, timbul hak dan kewajiban daerah yang dapat dinilai dengan uang, sehingga perlu dikelola dalam pengelolaan keuangan daerah. Pengelolaan Keuangan Daerah sebagaimana dimaksudkan merupakan sub sistem dari Sistem Pengelolaan Keuangan Negara dan merupakan elemen pokok dalam penyelenggaraan pemerintah.

Salah satu pelaksanaan Otonomi daerah di Negara Indonesia ini, sasaran utamanya adalah untuk meningkatkan Pendapatan Asli Daerah (PAD). Dalam pelaksaan otonomi daerah tersebut diserahkan untuk mencapai tujuan nasional sebagaimana dimuat dalam pembukann UndangUndang tentang Pemerintah Daerah Nomor 22/1999 yang pelaksaannya dilakukan secara bertahap sesuai dengan prioritasnya, yaitu pendekatan yang bersifat menyeluruh mempunyai sasaran jangka panjang ialah agar aparature Pemerintah dapat menjadi alat yang efisien, efektif, bersih, dan berwibawa untuk menjalankan peranannya dalam mendukung proses pembangunan nasional. Pelaksanaan secara bertahap sesuai dengan urutan prioritasnya dimaksudkan bukan dengan segera, melainkan juga agar tenaga, biaya, keahlian serta waktu yang tersedia dapat digunakan secara optimal.

Berdasarkan penjelasan diatas dapat diketahui bahwa aparat Pemerintah Daerah pemegang peran dalam pelaksaan Otonomi Daerah. Agar otonomi Daerah di Indonesia dapat berhasil dengan baik. Aparat Pemerintah Daerah terutama dari tingkat gross roots inilah yang pada akhirnya menjadi pelaksana-pelaksana dalam kegiatan usaha pemerintah. Oleh karena itu agar keberhasilan Otonomi Daerah dapat tercapai dengan baik diperlukan faktor-faktor pendukung, salah satunya melalui kemampuan pelaksana dari pegawai itu sendiri. Dengan kemampuan pelaksana tersebut akan mendukung keberhsilan otonomi Daerah yang telah direncanakan, sehingga dapat mencapai PAD yang telah ditetapkan.

Hal tersebut sesuai Dengan pendapat dari J.Sulamto (2004:20) bahwa "Tujuan Otonomi Daerah tersebut hanya dapat dilaksanakan secara bertahap dan sungguh-sungguh". Otonomi daerah hanya dapat dilaksanakan dengan berdaya guna dan berhasil guna di bawah pimpinan pemerintah yang stabil dan berwibawa dan didukung dengan hasil maupun kemampuan pelaksana dari pegawai pemerintah yang sempurna. Kesempurnaan pemerintah pada pokoknya tergantung pada hasil atau prestasi kerja para pelaksana. Otonomi daerah memiliki implikasi yang luas padahal kewenangan daerah untuk menggali dan mengelola sumber-sumber pendapatan daerah dalam rangka pembangunan dan kesejahteraan masyarakat di daerah, dengan demikian sebenarnya daerah memiliki peluang untuk lebih mengoptimalkan potensi-potensi daerah yang dimiliki. Namun diakui atau tidak bahwa sampai saat ini terbukti sebagian besar sumber-sumber pendapatan pemerintah daerah masih berasal dari sektor pajak. Sehingga optimalisasi pengelolaan pajak harus ditingkatkan.

\section{Permasalahan Penelitian}

Pertumbuhan jumlah pengguna kendaraan di kota Pekalongan terutama yang menggunakan jasa perparkiran di Mall-Mall Kota Pekalongan, sebenarnya merupakan potensi yang besar untuk mendapatkan pelayanan parkir yang memadai, akan tetapi pada kenyataannya infrastruktur pelayanan dan pengelolaan parkirnya cenderung belum optimal. Akibatnya penerimaan pajak parkirnya juga belum optimal. 


\section{WAWASAN DAN RENCANA PEMECAHAN MASALAH}

\section{Pengertian Pajak Secara Umum \\ a. Pengertian Pajak}

Prof. Dr. Rochmat, SH, yang di kutip dari buku perpajakan karangan Dr. Mardiasmo, MBA,. Ak (2011:11) Pajak adalah iuran rakyat kepada kas negara berdasarkan undang-undang (yang dapat dipaksakan) dengan tidak mendapat jasa timbal balik (kontraprestasi) yang langsung dapat ditunjukkan, dan yang digunakan untuk membayar pengeluaran umum. Pajak dalam bahasa Arab disebut kharaj yang berarti mengeluarkan. Secara terminologi kharaj adalah sejenis pajak yang dikeluarkan pada tanah yang ditaklukan dengan senjata, terlepas dari apakah si pemilik seorang muslim. Dalam pengertian lain, kharaj adalah sesuatu yang di keluarkan. Misalnya dengan dikeluarkannya pungutan dari hasil tanah pertanian. Dapat dikatakan pula bahwa kharaj adalah hasil bumi yang dikenakan pajak atas tanah yang di miliki oleh non muslim. Dalam istilah lain kharaj adalah uang sewa yang menjadi milik Negara akibat pembebasan tanah itu oleh tentara Islam. Tanah itu dipandang sebagai milik Negara dan di sewakan kepada penduduk muslimin dan yang bukan muslimin.

Secara terminologi pajak merupakan iuran yang di pungut oleh Pemerintah kepada rakyat yang sifatnya bisa di paksakan, tanpa memandang kaya atau miskin. Iuran pajak yang dapat dipungut oleh Pemerintah ini akan digunakan untuk membiayai pengeluaran pengeluaran Negara.

\section{b. Fungsi Pajak}

Di lihat dari definisinya, pajak mempunyai fungsi untuk membiayai pengeluaranpengeluaran Negara. Namun fungsi tersebut hanyalah salah satunya, karena pajak memiliki fungsi lain yaitu :

1) Fungsi Penerimaan (budgetair)

Dalam fungsi Penerimaan pajak berfungsi untuk mengisi kas, sebagai anggaran pendapatan Negara yang digunakan untuk membiayai pengeluaranpengeluaran Negara.

2) Fungsi Mengatur (regulerend)

Pajak berfungsi sebagai alat untuk membantu atau melaksanakan kebijakan Negara di bidang sosial dan ekonomi.

\section{c. Dasar-dasar Pemungutan Pajak}

Adam Smith memberikan lima dasar/asas pemungutan pajak sebagai berikut:

1) Asas falsafah hukum.

Falsafah hukum adalah keadilan, artinya pemungutan pajak terhadap rakyat harus adil dan merata sesuai kemampuan rakyat untuk membayar pajak dan sesuai dengan manfaatnya yang diterimanya.

2) Asas yuridis.

Asas ini menganjurkan pagar pemungutan Pajak berdasarkan hukum (undang-undang) sehingga ada kepastian tentang bagaimana prosedur dan dasar perhitungan pajak. Berapa pajak yang harus dibayar, kapan pajak harus dibayar, dan siapa saja yang harus membayar pajak sehingga tidak ada yang saling dirugikan salam pemungutan pajak.

3) Asas ketepatan.

Dalam pemungutan pajak sebaiknya negara memperhatikan saat-saat wajib pajak tidak mengalami kesulitan membayar pajak.

4) Asas ekonomi.

Agar tidak mengganggu tingkat produktifitas rakyat, maka besarnya pajak yang ditanggung oleh rakyat harus sesuai dengan kemampuan rakyat. Jangan sampai pembebanan pajak kepada rakyat dapat menurunkan tingkat produktifitas rakyat dalam kegiatan ekonominya.

5) Asas efisiensi. 
Pemungutan pajak harus efektif dan efisien, artinya pemungutan pajak harus tepat sasaran dan hasil perolehan pajak harus lebih besar daripada biaya

\section{d. Jenis-jenis Pajak}

pemungutan pajak yang dikeluarkan.

Pajak dapat dikelompokkan menjadi beberapa jenis, yaitu pengelompokan menurut golongan, menurut sifat dan menurut lembaga penuntutannya.

1) Jenis Pajak Menurut Golongannya

a. Pajak Langsung

Pajak langsung adalah pajak yang apabila beban pajak yang dipukul seseorang atau badan (tax burden) tidak dapat dilimpahkan (no tax shifting) kepada pihak lain.

b. Pajak Tidak Langsung

Pajak tidak langsung adalah beban pajak yang dipukul seseorang (tax burden) dapat dilimpahkan (tax shifting) baik seluruhnya maupun sebagian kepada pihak lain.

2) Jenis Pajak Menurut Sifatnya

a. Pajak Subyektif

Pajak Subyektif adalah pajak yang erat hubungannya dengan keadaan subyeknya, memperhatikan keadaan diri Wajib Pajak yang selanjutnya dicari syarat obyektivitasnya.

b. Pajak Obyektif

Pajak Obyektif adalah pajak yang berpangkal pada obyeknya tanpa memperhatikan diri Wajib pajak. Sehingga besarnya jumlah pajak hanya tergantung kepada keadaan obyek pajak tersebut.

3) Jenis Pajak Menurut Lembaga Pemungutannya

a. Pajak Pusat (Negara) Negara.

Pajak yang di pungut pemerintah pusat untuk membiayai pengeluaran

Contoh :

- Pajak Penghasilan(PPh)

- Pajak Bumi dan Bangunan (PBB)

- Pajak Pertambahan Nilai dan Pajak Penjualan Barang Mewah (PPn dan PPBM)

- Bea Materai

- Bea Perolehan Hak atas Tanah dan Bangunan (BPHTB)

b. Pajak Daerah

Pajak yang dipungut oleh pemerintah dan digunakan untuk membiayai

\section{e. Pajak Daerah} pengeluaran Daerah.

Adalah Pajak negara yang diserahkan kepada daerah untuk dipungut berdasarkan undang-undang yang dipergunakan untuk membiayai pengeluaran daerah sebagai badan hukum publik.

Pajak Daerah dibedakan menjadi dua:

1) Pajak Propinsi (Daerah tingkat $I$ )

- Pajak Kendaraan Bermotor dan Kendaraan di atas Air.

- Pajak Bahan Bakar Kendaraan Bermotor.

- Pajak Pengambilan dan Pemanfaatan Air Bawah Tanah dan Air Permukaan.

- Bea Balik Nama Kendaraan Bermotor dan Kendaraan diatas Air.

2) Pajak Kabupaten/Kota (Daerah tingkat II)

Jenis Pajak didalam kabupaten/kota adalah:

- Pajak Hotel.

- Pajak Restoran. 
- Pajak Hiburan.

- Pajak Reklame.

- Pajak pengambilan Bahan Galian Golongan C.

- Pajak penerangan jalan.

- Pajak Parkir.

\section{f. Syarat Pemungutan Pajak}

Pemungutan pajak harus memenuhi syarat-syarat tertentu guna menghindari perlawanan pajak yaitu :

1) Pemungutan pajak harus adil.

2) Pemungutan pajak harus berdasarkan undang-undang.

3) Pemungutan pajak tidak mengganggu perekonomian.

4) Pemungutan pajak harus efisien.

5) Sistem pemungutan pajak harus sederhana.

\section{Pajak Parkir}

\section{a. Pengertian Pajak Parkir}

Parkir adalah memangkalkan/menempatkan kendaraan bermotor diluar badan jalan baik yang di sediakan berkaitan dengan pokok usaha maupun yang disediakan sebagai suatu usaha termasuk penyediaan tempat titipan. Adapun pengertian Pajak Parkir menurut Peraturan Daerah Kota Makasar Pasal 1 Nomor 13 tahun 2002 tentang pajak parkir di jelaskan sebagai berikut:

"Pajak Parkir yang selanjutnya di singkat pajak adalah penguatan yang dikenakan atas penyelenggaraan usaha tempat parkir yang dikelola orang atau badan".

Sedangkan pengertian Pajak parkir Menurut Marihot P. Siahaan (Dalam Syahrul, 2016:41) "pajak parkir adalah pajak yang dikenakan atas penyelenggaraan tempat parkir diluar badan jalan oleh orang pribadi atau badan, baik yang disediakan berkaitan dengan pokok usaha maupun yang disediakan sebagai suatu usaha, termasuk penyediaan tempat penitipan kendaraan bermotor dan garasi kendaraan bermotor yang memungut bayaran".

\section{b. Subjek Pajak Parkir}

Subjek pajak parkir Menurut Peraturan Daerah Nomor 13 tahun 2002 tentang pajak Parkir menyatakan bahwa:

"Subjek pajak parkir adalah orang pribadi atau badan yang menyelenggarakan usaha perparkiran swasta".

\section{c. Objek Pajak Parkir}

Menurut Undang-undang Nomor 28 tahun 2009 pasal 62, Objek pajak parkir yakni penyelenggara tempat parkir diluar badan jalan, baik yang disediakan berkaitan dengan pokok usaha maupun yang disediakan sebagai suatu usaha. Termasuk penyediaan tempat penitipan kendaraan bermotor dan garasi kendaraan bermotor.

\section{d. Wajib Pajak Parkir}

Wajib pajak parkir adalah orang pribadi/badan yang menyelenggarakan pembayaran atas tempat parkir.

\section{e. Dasar Hukum Pajak Parkir}

Undang-undang Nomor 28 tahun 2009 tentang Pajak Daerah dan Retribusinya Daerah. Peraturan daerah kota Pekalongan Nomor 9 tahun 2011 tentang Pajak Parkir.

\section{f. Tarif Pajak Parkir}

Pengertian dasar pengenaan pajak parkir menurut Djamu Kertabudi menyatakan bahwa "Dasar pengenaan pajak parkir adalah jumlah pembayaran atau yang seharusnya dibayar untuk pemakaian tempat parkir".

Tarif pajak parkir ditentukan dalam undang-undang Nomor 28 tahun 2009 tentang pajak parkir. Tarif tersebut berlakunya sama dengan tarif yang terdapat dalam UU pajak daerah, yaitu ditetapkan paling tinggi sebesar 30\% (tiga puluh persen), 
sehingga besarnya pokok Pajak Parkir yang terutang dihitung dengan cara mengalikan tarif dengan dasar pengenaan pajak.

\section{Pendapatan Asli Daerah}

a. Pengertian Pendapatan Asli Daerah

Pendapatan Daerah adalah hak pemerintah daerah yang diakui sebagai penambah nilai kekayaan bersih dalam periode tahun anggaran yang bersangkutan.

\section{b. Sumber-sumber Pendapatan Asli Daerah}

Sesuai dengan undang-undang Nomor 32 tahun 2004 pasal 157 ditetapkan bahwa sumber-sumber Pendapatan Asli Daerah (PAD) berasal dari:

1) Pendapatan Asli Daerah, meliputi :

- Hasil pajak daerah

- Hasil retribusi daerah

- Hasil perusahaan milik daerah dan hasil pengelolaan kekayaan daerah yang dipisahkan, dan

- Lain-lain pendapatan daerah yang sah.

2) Dana Perimbangan

Dana Perimbangan adalah dana yang bersumber dari pendapatan APBN yang di alokasikan kepada daerah berdasarkan angka prosentase untuk mendanai kebutuhan daerah dalam rangka pelaksanaan desentralisasi.

Dana Perimbangan terdiri dari :

- Dana bagi hasil

- Dana Alokasi Umum (DAU)

- Dana Alokasi Khusus (DAK)

- Pendapatan daerah yang sah.

\section{RUMUSAN TUJUAN PENELITIAN}

Berdasarkan pemaparan pada pendahuluan dimuka dan dengan memperhatikan fokus penelitian pada batasan masalah, maka hal yang menjadi kajian penelitian yaitu: "Bagaimana potensi pajak parkir serta efisiensi pajaknya di mall-mall kota Pekalongan dan kontribusi terhadap Pendapatan Asli Daerah (PAD)". Kemudian tujuan yang ingin dicapai dalam penelitian ini adalah mengetahui potensi pajak parkir,efisiensi pajak di mall-mall serta kontribusi terhadap Pendapatan Asline Daerah (PAD).

\section{Metodologi Penelitian}

Pendekatan yang digunakan dalam penelitian ini adalah pendekatan kualitatif. Data diperoleh melalui wawancara yang dilakukan terhadap pihak yang ada hubungannya dengan teori mengenai topik penelitian yang di bahas. Teknik pengumpulan data pada penelitian ini terbagi dalam 2 jenis. Penelitian ini berdasarkan metode deskriptif yang digunakan dan bentuk penelitian yang merupakan survey. Teknik yang digunakan :

a) Penelitian Lapangan (Field Research)

Untuk mendapatkan data dalam penelitian ini dilakukan dengan wawancara kepada pihak-pihak yang terkait dengan topik penelitian.

b) Penelitian Kepustakaan (Library Research)

Penelitian ini diperoleh dari berbagai buku maupun artikel lainnya yang di gunakan sebagai landasan teori untuk mendapatkan data yang di perlukan.

\section{RANGKUMAN KAJIAN TEORITIK}

Kesimpulan yang diambil bahwa terdapat perbedaan antara mahasiswa akuntansi yang memilih karir sebagai akuntan publik, KUNTn perusahaan, akuntan pemerintah, dan akuntan 
pendidik ditinjau dari nilai intrinsik pekerjaan, penghagaan finansial, lingkungan kerja, pelatihan profesional, pengakuan profesional, nilai-nilai sosial dan pertimbangan pasar kerja.

Dari pembahasan pada masing-masing bab yang telah diuraikan sebelumnya maka terdapat beberapa kesimpulan antara lain :

- Satu pendapatan asli daerah sebagai salah satu sumber penerimaan daerah mempunyai peranan penting dalam pembangunan upaya untuk meningkatkan pendapatan asli daerah tentunya tidak terlepas dari peranan masing-masing komponen pendapatan asli daerah komponen yang ada seperti penerimaan pajak daerah retribusi daerah bagian laba perusahaan milik daerah penerimaan dinas dinas serta penerimaan Cara lainnya pajak parkir yang merupakan salah satu dari pajak daerah juga menjadi salah satu penunjang PAD.

- Adanya pemungutan pajak parkir selain penunjang secara tidak langsung juga dapat memberikan dampak positif baik terhadap pemerintahan Kota Pekalongan maupun terhadap masyarakat kota Pekalongan diantaranya dapat memberikan atau membuka lowongan kerja masyarakat kota Pekalongan dari keterangan diatas dapat disimpulkan bahwa pajak parkir menjadi salah satu komponen pajak daerah yang mendukung pembangunan kota Pekalongan

- Pajak parkir motor di mall kota pekalongan memberi sumbangan sebesar Rp. 61.884.000 dari jumlah pajak parkir di kota pekalongan yang sebesar Rp.9.760.627.000 atau pajak parkir motor di momo kota pekalongan memberi sumbangan hampir 0,63\% terdapat pajak parkir di kota pekalongan sedangkan pajak parkir mobil di mall kota pekalongan memberi sumbangan sebesar Rp. 11.232.000 dari jumlah pajak parkir di kota pekalongan yang sebesar Rp. 9.760.627.000 atau pajak parkir mobil memberi sumbangan hampir 0,12\% terhadap pajak parkir di kota Pekalongan. dan kontribusi ya terhadap PAD menyumbang sebesar 30\% dari pajak parkir Rp. 9.760.627.000.

\section{Penelitian Dan Pembahasan}

Berdasarkan latar belakang yang dipaparkan, dapat diambil suatu pembahasan yaitu "Bagaimana potensi pajak parkir dan efisiensi pajaknya di mall-mall kota Pekalongan serta kontribusi terhadap Pendapatan Asli Daerah."

Analisis efisiensi dimaksudkan untuk mengukur bagian dari hasil pajak yang digunakan untuk menutup biaya pemungutan pajak yang bersangkutan, atau dirumuskan sebagai berikut (Mahmudi, 2010)

\section{Efisiensi $=$ Biaya Pemungutan pajak $\times 100 \%:$ Realisasi pajak}

Penerimaan pajak dapat dikatakan efisien apabila realisasi penerimaan pajak lebih besar dari biaya pemungutan. semakin kecil rasio maka semakin efisien.

Analisis kontribusi yaitu suatu alat analisis yang digunakan untuk mengetahui seberapa besar kontribusi yang dapat disumbangkan dari penerimaan pajak parkir terhadap penerimaan Pendapatan asli daerah di Kota Pekalongan, maka dibandingkan antara realisasi penerimaan pajak parkir terhadap Pad. untuk mengetahui kontribusi pajak parkir terhadap pendapatan asli daerah menggunakan rumus

\section{Kontribusi $=$ Realisasi penerimaan pajak parkir $:$ Realisasi penerimaan PAD}

Analisis Potensi Pajak

Analisis ini digunakan untuk mengetahui seberapa besar potensi pajak parkir yang dapat dihitung dengan cara mengalikan rata-rata pendapatan harian dengan 360 hari kali tarif pajak parkir (Mahmudi, 2010: 70).

Dari tabel diatas dapat disimpulkan bahwa pajak parkir motor di Mall Kota Pekalongan memberi sumbangan sebesar Rp. 61.884.000 dari jumlah pajak parkir di Kota Pekalongan yang 
sebesar Rp. 9.760.627.000 atau pajak parkir motor di mall-mall Kota Pekalongan memberi sumbangan hampir 0,63\% terhadap pajak parkir di Kota Pekalongan. Sedangkan pajak parkir mobil di Kota Pekalongan memberi sumbangan sebesar Rp. 11.232.000 dari jumlah pajak parkir di Kota Pekalongan yang sebesar Rp. 9.760.627.000 atau pajak parkir mobil memberi sumbangan hampir 0,12\% terhadap pajak parkir di Kota Pekalongan.

Analisis kontribusi terhadap PAD, Dari hasil kajian kami tentang peraturan daerah Kota Pekalongan nomor 9 tahun 2011 tentang pajak parkir menunjukkan bahwa tarif pajak ditetapkan sebesar 30\% dari jumlah pembayaran sebagaimana dimaksud pada pasal 6 peraturan daerah.

Sebagaimana telah dijelaskan di depan sumber-sumber PAD berasal dari hasil Pajak Daerah dan Retribusi Daerah. Pajak parkir yang merupakan salah satu dari pajak daerah juga menjadi salah satu Penunjang PAD.

Dari tabel diatas dapat disimpulkan bahwa pajak parkir di Kota Pekalongan memberikan kontribusi sebesar 30\% Daripada di kota Pekalongan yaitu sebesar Rp. 9.760.627.000. Prosentase hasil pajak parkir inilah yang ikut menunjang PAD, sedangkan PAD itu sendiri merupakan salah satu pendapatan yang digunakan untuk membiayai kepentingan daerah,

Pembangunan Daerah, belanja daerah dan lain-lain.

Seperti yang dikemukakan oleh pegawai dinas pendapatan daerah Kota Pekalongan "seperti yang kita ketahui bahwa pajak parkir itu merupakan salah satu dari pajak daerah hasil dari pajak parkir ini nanti akan dijadikan satu dengan pajak-pajak lainnya dan juga penerimaan daerah lainnya yang nantinya akan digunakan untuk anggaran memenuhi belanja daerah dan juga kebutuhan daerah, terpenuhinya target yang ditetapkan tidak luput dari kerja keras kami dalam menggali potensi-potensi pajak parkir yang ada".

Hal serupa juga dikatakan oleh salah satu pengelola parkir di Mall Kota Pekalongan "yang jelas hasil dari pajak parkir ini nanti akan dijadikan satu dengan pajak Pajak lainnya dan penerimaan pendapatan daerah lainnya yang akhirnya semuanya digunakan untuk kebutuhan rumah tangga Daerah seperti Pembangunan Daerah dan lainnya".

Adapun tata cara pembayaran pajak parkir di Kota Pekalongan antara lain:

1. pembayaran pajak dilakukan di Dinas Daerah atau tempat lain yang ditunjuk oleh kepala

daerah sesuai waktu yang ditentukan dalam SPTPD, SKPD, SKPDKB, SKPDKB, dan

STPD.

2. apabila pembayaran pajak dilakukan di tempat lain yang ditunjuk hasil penerimaan pajak

harus disetor ke kas daerah selamat lambatnya 1 kali 24 jam atau dalam waktu yang

ditentukan oleh kepala daerah.

3. pembayaran pajak dilakukan dengan menggunakan SSPD.

Adanya pemungutan pajak parkir selain menunjang PAD, secara tidak langsung juga dapat memberikan dampak positif baik terhadap pemerintahan kota pekalongan maupun terhadap masyarakat kota pekalongan di antaranya, dapat memberikan atau membuka lowongan kerja masyarakat kota Pekalongan. oleh karena itu selain untuk menunjang PAD. pajak parkir juga bermanfaat terhadap sebagian masyarakat karena pajak parkir bisa dijadikan sebagai salah satu pekerjaan bagi sebagian orang, hal ini tentunya bisa mengurangi walaupun sedikit pengangguran di daerah pekalongan, mengingat kondisi sekarang di mana mencari kerja itu sangat sulit.

Hal ini berdasarkan hasil wawancara dengan juru parkir di hypermart plaza pekalongan yang mana beliau mengatakan "dengan adanya parkir ini kami bisa mendapatkan pekerjaan sebagai juru parkir harian yang mana setiap harinya kami di gaji sebesar Rp25.000 dan itu cukup bagi kami untuk biaya hidup sehari-hari."

Juru parkir trans mart juga mengatakan hal yang sama sekarang cari kerja sulit pekerjaan saya ya cuma jadi juru parkir rupanya tergantung ramai dan sepinya pengunjung tapi biasanya 20000 sampai Rp30.000 lumayan untuk memenuhi kebutuhan sehari-hari.

Dari hasil wawancara di atas maka dapat disimpulkan bahwa selain untuk menunjang PAD. Pajak parkir juga bermanfaat terhadap sebagian masyarakat karena pajak parkir bisa dijadikan sebagai salah satu pekerjaan bagi sebagian orang, hal ini tentunya bisa mengurangi walaupun 
sedikit pengangguran di daerah pekalongan, mengingat kondisi sekarang dimana mencari kerja itu sangat sulit.

Sebagaimana yang kita ketahui bahwasannya pajak merupakan iuran wajib rakyat kepada negara dari pajak ini yang mana akan digunakan untuk membiayai kegiatan pemerintahan. sejak tahun 1999 pembagian pajak menurut wewenang pemungutan pajak dipisahkan menjadi pajak pusat dan pajak daerah. pajak pusat yang dipungut oleh pemerintah pusat terdiri dari pajak penghasilan dan pajak pertambahan nilai untuk pajak daerah di pungut oleh pemerintah daerah itu sendiri.

dasar dilakukan pemungutan oleh pemerintah daerah sesuai dengan Undang-Undang nomor 25 tahun 1999 tentang otonomi daerah mengatakan bahwa pemerintah dan masyarakat di daerah dipersilahkan mengurus rumah tangganya sendiri secara bertanggung jawab. pemerintah pusat tidak lagi patronasi apalagi mendominasi mereka pemerintah pusat tidak lagi 4 rona siapa lagi mendominasi mereka peran pemerintah pusat dalam konteks desentralisasi ini adalah melakukan supervisi memantau mengawasi dan mengevaluasi pelaksanaan otonomi daerah dengan adanya otonomi daerah maka pemerintah daerah diberikan wewenang untuk mengatur dan mengurus rumah tangga daerahnya langkah-langkah yang perlu diambil dengan cara menggali segala kemungkinan sumber keuangannya sendiri sesuai dengan dan dalam batasbatas peraturan perundang-undangan yang berlaku.

untuk merealisasikan pelaksanaan otonomi daerah maka sumber pembiayaan pemerintah daerah tergantung pada peranan padahal ini diharapkan dan diupayakan dapat menjadi penyangga utama dalam membiayai kegiatan pembangunan di daerah oleh karena itu pemerintah daerah harus dapat mengupayakan peningkatan penerimaan yang berasal dari daerah sendiri sehingga akan memperbesar tersedianya keuangan daerah yang dapat digunakan untuk berbagai kegiatan pembangunan dengan ini akan semakin memperbesar keleluasaan daerah untuk mengarahkan penggunaan keuangan daerah sesuai dengan rencana skala prioritas dan kebutuhan daerah yang bersangkutan.

Merupakan pencar mainan dari pelaksanaan otonomi di daerah. untuk melihat kemampuan pemerintah kota pekalongan dalam menghimpun penerimaan daerah baik penerimaan yang berasal dari sumbangan dan bantuan pemerintah pusat maupun penerimaan yang berasal dari daerah sendiri. hal ini dapat dilihat dalam APBD yang biayanya bersumber dari PAD dengan tingkat kesesuaian yang mencukupi pengeluaran pemerintah daerah.

Upaya untuk meningkatkan pendapatan asli daerah tentunya tidak terlepas dari peranan masingmasing komponen pendapatan asli daerah. komponen yang ada seperti penerimaan pajak daerah, retribusi daerah, bagian laba perusahaan milik daerah, penerimaan dinas-dinas serta penerimaan daerah lainnya.

Jenis-jenis pajak daerah yang ditetapkan dan dapat dipungut oleh pemerintah kota pekalongan dalam upaya menghimpun dana guna meningkatkan kualitas maupun kuantitas pembangunan daerah saat ini terdiri atas 6 jenis pajak daerah atau (Dispenda pekalongan), antara lain pajak hotel dan restoran, pajak pajak hiburan, pajak reklame, pajak penerangan jalan, pajak pengambilan dan pengolahan bahan galian golongan $\mathrm{C}$ dan pajak parkir.

Hal serupa juga diucapkan oleh pegawai dinas pendapatan daerah kota pekalongan "Hasil dari pajak parkir ini nanti akan dijadikan satu dengan panca kocak lainnya dan juga penerimaan penerimaan daerah lainnya yang akhirnya digunakan untuk menunjang PAD, PAD itu sendiri digunakan untuk pembangunan daerah dan untuk memenuhi kebutuhan daerah"

\section{PENELITIAN TERDAHULU}

Penelitian terdahulu berguna sebagai masukkan masukkan agar dapat memberikan arahan kinerja dan memperkuat definitif pada penelitian yang akan dilakukan oleh peneliti saat ini. peneliti terdahulu tersebut meliputi :

1. Didik Tandika, (2005), perparkiran di kota bandung dan kontribusinya terhadap Penerimaan Asli Daerah (PAD)kota BANDUNG. Hasil penelitian ini menyimpulkan bahwa Unit Pengelolaan Perparkiran (UPP) kota Bandung secara kelembagaan memiliki berbagai keterbatasan dalam pengelolaan perkiraan (on street) baik dari sisi kewenangan, 
keorganisasi, kemampuan sumber daya manusia, maupun sarana dan prasarana lainnya dan dalam pengelolaan perparkiran UPP juga memiliki kendala infrastruktur jalan raya yang tidak bertambah dibandingkan dengan luas wilayah kota Bandung dan juga terhadap pertambahan jumlah kendaraan yang terus bertambah seiring dengan bertambahnya jumlah penduduk kota Bandung dan pemerintah kota Kandung belum dapat meningkatkan realisasi retribusi parkir melebihi $100 \%$.

2. Ika Muthoharoh, (2009), perang pajak parkir dalam menunjang Pendapatan Asli Daerah (PAD) di kota Malang. Hasil penelitian ini menyimpulkan bahwa pendapatan asli daerah sebagai salah satu sumber penerimaan daerah mempunyai peranan penting dalam pembangunan. Upaya untuk meningkatkan pendapatan asli daerah tentunya tidak terlepas dari peranan masing-masing komponen pendapatan asli daerah dan adanya pemungutan pajak parkir selain menunjang PAD, secara tidak langsung juga dapat memberikan dampak positif baik terhadap pemerintahan kota malang maupun terhadap masyarakat kota malang di antaranya, dapat memberikan atau membuka lowongan kerja masyarakat kota malang.

3. Rahmawati,(2012), Analisis efektivitas pajak dan retribusi parkir di kabupaten tangerang. Hasil penelitian ini menyimpulkan bahwa penelitian ini yang menunjukkan target penerimaan pajak dan retribusi parkir tidak sesuai dengan potensi yang sebenarnya yang diiringi dengan tercapainya realisasi yang mampu melebihi target yang direncanakan. Naik dan turun nya kontribusi pajak dan retribusi parkir dipengaruhi oleh banyak sedikitnya penyediaan lahan parkir, pembangunan Mall besar, dan kurangnya pengawasan petugas Dishub dalam pemungutan retribusi parkir yang menyebabkan sulitnya memberantas parkir liar di kabupaten tangerang.

\section{PERSAMAAN}

Penelitian ini mempunyai persamaan dengan penelitian terdahulu penelitian yang dilakukan oleh Dikdik Tandika (2005) mempunyai persamaan dengan penelitian yang akan dilakukan yaitu meneliti tentang perparkiran dan pengaruhnya terhadap Pendapatan Asli Daerah (PAD), penelitian yang dilakukan Ika Muthoharoh (2009) mempunyai persamaan peran dari pajak parkir dalam meningkatkan Pendapatan Asli Daerah (PAD), penelitian yang dilakukan oleh Rahmawati (2012) mempunyai persamaan meneliti tentang pajak parkir.

\section{Saran}

Penulis menyarankan beberapa hal terkait dengan pembelajaran diatas antara lain:

Pertama, pengembangan dan pengadaan media untuk mempermudah proses penelitian. Kedua, menambah variabel penelitian. Ketiga, melakukan penelitian terhadap potensi pajak parkir di Mall-Mall Kota lain.

\section{Ucapan Terimakasih}

Dengan terselesaikannya karya ilmiah ini, penulis mengucapkan terimakasih kepada:

1. Allah SWT. atas limpahan karunia dan hidayahnya sehingga penulis dapat melaksanakan penelitian dan menyelesaikan karya ilmiah.

2. Ibu Dosen Lita Dwi Ariyanti, M.Pd selaku dosen Bahasa Indonesia atas bimbingan dan arahan dan koreksi selama penyusunan artikel.

3. Kedua Orang Tua saya yang telah membantu dan mendukung saya dalam mengerjakan karya ilmiah ini.

4. Mahasiswa di Pekalongan atas kerjasamanya. 
Daftar Pustaka

[1] Mardiasmo. 2011. Perpajakan. Yogyakarta. Andi Offset.

[2] Azhari.A.Samudra. 2005. Perpajakan di Indonesia Keuangan, Pajak \& Retribusi. Jakarta. HECCA Publishing.

[3] Dikdik Tandika. 2005. Perparkiran di Kota Bandung dan Kontribusi ya terhadap Penerimaan Asli Daerah (PAD) Kota Bandung. Bandung : Universitas Bandung.

[4] Djumhana Muhammad. 2007. Pengantar Hukum Keuangan Daerah. Bandung : PT. Citra Aditya Bakti.

[5] Hunger, J. David dan Thomas. L. Whelen. 2003. Manajemen Strategi. Andi : Yogyakarta.

[6] Ika Muthoharoh. (2009). Peran Pajak Parkir dalam Menunjang Pendapatan Asli Daerah (PAD) di Kota Malang. Malang: Universitas Islam Negeri, Malang.

[7] J. Sulamto. 2004. Otonomi Daerah. Gramedia : Jakarta.

[8] Kencana, Inu. 1999. Ilmu Administrasi Publik. Rineka CIPTA : Jakarta.

[9] Kesit, Bambang Prakosa. 2005. Pajak dan Retribusi Daerah. Cetakan Kedua. Yogyakarta : UII Press.

10] Mahmudi. 2010. Manajemen Keuangan Daerah, Yogyakarta : UPP STIM YKPN.

[11] Mardiasmo. 2004. Otonomi dan Manajemen Keuangan Daerah. Yogyakarta : Andi Offset.

[12] Mardiasmo. 2009. Perpajakan Edisi Revisi. Yogyakarta : C.V Andi Offset.

[13] Erlina, Sri Mulyani. 2007. Metodologi Penelitian Bisnis. USU press, Medan.

[14] Pemerintah Republic Indonesia, UU No. 34 Tahun 2000 tentang Pajak dan Retribusi Daerah.

[15] Pemerintah Republik Indonesia, UU No. 28 Tahun 2009 tentang Pajak dan Retribusi Daerah. 